\title{
Decadal variability in chlorophyll and primary production off NW Spain
}

\author{
Antonio Bode ${ }^{1, *}$, Ricardo Anadón ${ }^{2}$, Xosé Anxelu G. Morán ${ }^{3}$, Enrique Nogueira ${ }^{3}$, \\ Eva Teira ${ }^{4}$, Manuel Varela ${ }^{1}$
}

\author{
${ }^{1}$ Centro Oceanográfico de A Coruña, Instituto Español de Oceanografía, Apdo. 130, 15080 A Coruña, Spain \\ ${ }^{2}$ Depto. Biología de Organismos y Sistemas, Universidad de Oviedo, Campus del Cristo, 33071 Oviedo, Spain \\ ${ }^{3}$ Centro Oceanográfico de Gijón, Instituto Español de Oceanografía, Avda. Príncipe de Asturias 70b, 33212 Gijón/Xixón, Spain \\ ${ }^{4}$ Depto. de Ecoloxía e Bioloxía Animal, Universidade de Vigo, Campus Lagoas-Marcosende, 36210 Vigo, Spain
}

\begin{abstract}
Long-term variability of phytoplankton biomass (chlorophyll a) and primary production (carbon fixation) in relation to changes in climatic and oceanographic factors was analysed for oceanic and shelf waters of the north and northwest Iberian Peninsula. Changes related to stratification in the water column and upwelling intensity were specifically addressed. The time series include measurements of primary production and biomass over $19 \mathrm{yr}$. Seasonally, the main mode of temporal variability of the series is the occurrence of phytoplankton blooms during the winter-spring and summer-autumn transition periods. On the northwestern coast (Galicia), the blooms are more frequent and attain higher biomass and production values than on the northern coast (Mar Cantábrico) due to the longer duration and higher intensity of upwelling in the former region. Even for the longest series there is no significant long-term trend in biomass, but primary production increased in Galicia and decreased in the Mar Cantábrico at nearly equivalent rates when considering monthly series. The lagged relationships between external factors and phytoplankton biomass and production suggest non-linear interactions between phytoplankton and climate. Neither the increase in surface stratification nor the decrease in upwelling intensity has negatively affected primary production in this region following consistent and systematic patterns. Changes in the amount and proportions of nutrients during winter water-mass formation, and an increased use of nutrients remineralised in situ, are proposed as the main causes of decadal variability in primary production in this region.
\end{abstract}

KEY WORDS: Primary production - Upwelling $\cdot$ Climate change $\cdot$ Nutrients $\cdot$ Remineralisation $\cdot$ NE Atlantic

\section{INTRODUCTION}

Phytoplanktonic photosynthesis in the ocean absorbs $>100 \mathrm{Tg}$ of carbon daily (Behrenfeld et al. 2006). This process causes a substantial reduction in excess atmospheric $\mathrm{CO}_{2}$, thus helping to moderate global warming (IPCC 2007). The availability of nutrients and light in the surface layer are the main factors controlling primary production. Adequate light levels only reach a relatively thin layer of the surface ocean. Nutrients are rapidly consumed by phytoplankton and their replenishment depends mostly on vertical mixing, mainly through thermal convection and winddriven turbulence in winter, while the heat absorbed by the surface layers tends to reinforce vertical stratification. Warming of surface waters was detected at significant rates in almost all ocean regions (Sherman \& Hempel 2009). The increasing thermal gradient between the surface and sub-surface layers may reduce the input of nutrients to the illuminated euphotic layer where primary production occurs. As a result, large areas of the major oceans have a reduced ability to capture $\mathrm{CO}_{2}$ through phytoplankton photosynthesis (McClain et al. 2004, Gregg et al. 
2005, Behrenfeld et al. 2006, Vantrepotte \& Mélin 2009).

Primary production in large areas of the oceans depends on wind-driven upwelling of nutrient-rich deep waters. Such ecosystems, located at both sides of the equator and on the western shelves of the continents, account for about $10 \%$ of oceanic new production, despite representing $<1 \%$ of the world ocean by area (Fréon et al. 2009). New production relies on nutrients provided from external sources (new nutrients) and allows for a net export of organic matter to sediments and upper trophic levels of the food web. In contrast, production based on nutrients remineralised in situ from organic matter (regenerated nutrients) only sustains food webs based on microbes with no net export of organic matter (Bode et al. 2004). Because of the differential warming of the land and ocean, an increase in upwelling-favourable winds has been predicted as a result of global warming (Bakun 1990). This increase has been shown as a cooling of surface waters in some regions (Mendelssohn \& Schwing 2002, McGregor et al. 2007) and led to an augmentation of phytoplankton biomass in the major upwelling regions (Gregg et al. 2005, Vantrepotte \& Mélin 2009).

The upwelling ecosystem off northwestern Africa extends over the western Iberian Peninsula, forming one of the world's large marine ecosystems (Longhurst 2007), which sustain high yields in fisheries and aquaculture (Sherman \& Hempel 2009). High levels of primary production are primarily related to the nutrient inputs by upwelling and its amplification by remineralisation processes in the coastal inlets of the Galician rias (Bode et al. 1996, Álvarez-Salgado et al. 2002). Upwelling is less important for production in the Mar Cantábrico (southern Bay of Biscay), where nutrient fertilisation depends mostly on the deep convection occurring during winter (Botas et al. 1990). Most studies on the variability of primary production and biomass in this region have focused on the effects of the inputs of new nutrients at short-term and local scales (Fernández \& Bode 1991, Casas et al. 1997, Llope et al. 2007) and only limited information exists on interannual changes at the regional scale (Álvarez-Salgado et al. 2002). In contrast to other upwelling events, recent studies have pointed out a multidecadal decrease in the intensity of upwelling (e.g. Lemos \& Sansó 2006) and changes in plankton biomass and composition (Llope et al. 2007, Bode et al. 2009, Huete-Ortega et al. 2010, Pérez et al. 2010).

The objective of the present study was to analyse long-term trends in phytoplankton biomass and primary production in the upwelling ecosystem off NW Spain with emphasis on their relationship to changes in large-scale forcing factors related to climate, such as those related to changing atmospheric pressure fields and coastal upwelling. The working hypothesis was that the increase in temperature in surface waters would enhance stratification, and in turn reduce the input of nutrients into surface waters. This effect would be amplified by the decreasing intensity of upwelling, and would lead to measurable decreases in the biomass and production of phytoplankton. A comparative analysis of the differential effect of environmental factors on primary production on the western coast (Galicia) and the northern coast (Mar Cantábrico) was made using time series of observations from satellite-borne sensors and in situ measurements.

\section{MATERIALS AND METHODS}

Phytoplankton biomass was estimated from chlorophyll a concentrations measured in situ or estimated from satellite-borne sensors. Measurements at sea were obtained from the time-series stations of the project RADIALES (www.seriestemporales-ieo.net), in operation since 1987 in NW Spain (Valdés et al. 2007). Details of sampling and additional information on these time series can be found in Casas et al. (1997) and Llope et al. (2007). Briefly, water samples were collected monthly at each location with Niskin bottles at up to 8 depths simultaneously with CTD casts (Seabird SBE-25 or SBE-911). Five stations with maximum depths between 80 and $110 \mathrm{~m}$ and distributed along

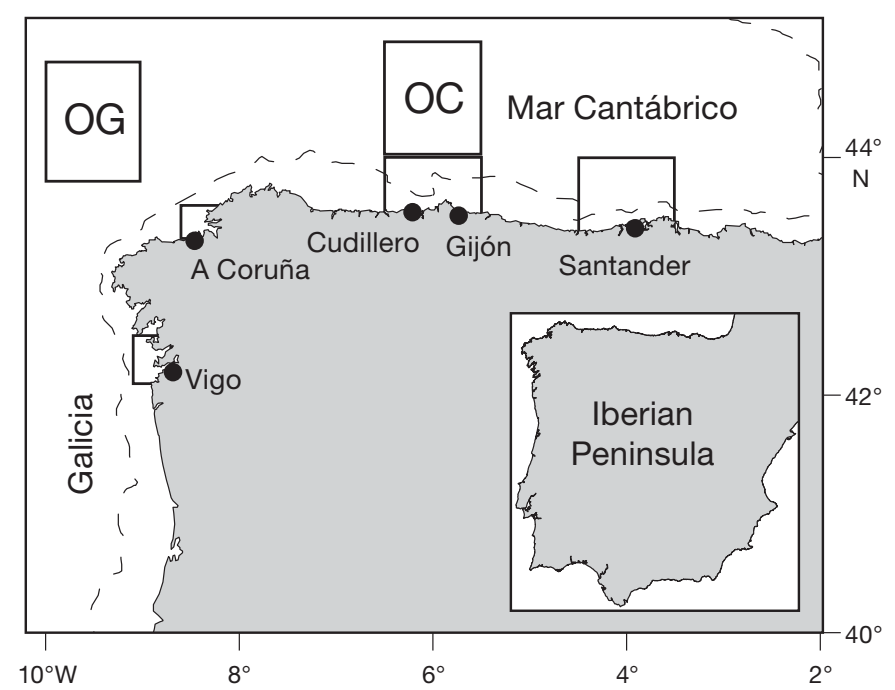

Fig. 1. Study area. Coastal time-series sites for chlorophyll (all sites) and primary-production (only in A Coruña and Cudillero) measurements. Sampling sites were characteristic of Galicia (Vigo and A Coruña) and Mar Cantábrico (Cudillero, Gijón and Santander) regions. The weekly SeaWiFS satellite observations were averaged for each of the coastal and oceanic areas inside the marked rectangles. The $200 \mathrm{~m}$ isobath is marked (dashed line). OG: oceanic Galicia, OC: oceanic Mar Cantábrico 
the coast were selected for the present study (Fig. 1). Chlorophyll a concentration was determined from samples collected on GF/F filters, extracted in $90 \%$ acetone overnight and measured fluorometrically (Parsons et al. 1984). Recent samples from the series of $\mathrm{A}$ Coruña (since 2000) and Gijón (since 2001) were analysed using the spectrofluorometric method (Neveux \& Panouse 1987). In these cases, intercalibration adjustments between methods were made to ensure the compatibility of the series. These series are the largest collection of field measurements of chlorophyll in the region, covering the period 1989 to 2007 with different lengths of time according to the start of sampling at each location.

Satellite-derived chlorophyll concentration allowed for a more detailed analysis of phytoplankton distribution over large areas and with higher temporal resolution than measurements at fixed stations. In the present study we collected $8 \mathrm{~d}$ averaged surface chlorophyll values estimated from the Sea-viewing Wide Field-of-view Sensor (SeaWiFS) available for the period 1998 to 2007 . Data from $9 \times 9 \mathrm{~km}$ pixels (level 3, reprocess 5.2, data accessed in June 2009, http://reason.gsfc.nasa.gov/Giovanni/) were averaged in different areas that are considered representative of different coastal and oceanic environments through the region (Fig. 1).

Primary-production measurements were made only in A Coruña and Cudillero using water samples from 3 to 5 depth levels distributed through the euphotic zone and obtained along with those for chlorophyll determinations. Samples were inoculated with inorganic ${ }^{14} \mathrm{C}$ and incubated in simulated temperature and irradiance conditions equivalent to those of the original sampling depth (Bode et al. 1996, Llope et al. 2007). Incubations lasted for up to $3 \mathrm{~h}$ at noon and the measured carbon uptake rates were scaled to daily primary-production rates using the photoperiod for each sampling date. No corrections for respiration were made and the estimates were assumed to be close to gross production rather than to net production. For comparative purposes, and taking into account that the euphotic zone in the shelf varied between 30 and $45 \mathrm{~m}$ (Bode et al. 2004), the chlorophyll and primaryproduction series were integrated down to $80 \mathrm{~m}$ (A Coruña) or $110 \mathrm{~m}$ (Cudillero) in the water column before statistical analysis.

Large-scale environmental forcing was represented by the winter-averaged (December to March) and summer-averaged (June to August) North Atlantic Oscillation (NAO) index, measuring the difference in atmospheric pressure between Iceland and the Azores (Barnston \& Livezey 1987, Folland et al. 2009); the Atlantic Multidecadal Oscillation (AMO), measuring anomalies in sea surface temperature (SST) (Delworth
\& Mann 2000); and the upwelling index (UI), derived from Ekman transport computed in a $2^{\circ} \times 2^{\circ}$ grid centred at $43^{\circ} \mathrm{N}, 11^{\circ} \mathrm{W}$ from geostrophic winds (Lavin et al. 2000, Pérez et al. 2010). Local-scale factors were indicated by seawater temperature, density $\left(\sigma_{t}\right)$ and dissolved nutrients. Temperature and density were determined from CTD profiles. SST was intended as an indicator of the local effect of global warming, while the degree of stratification was represented by the standard deviation of temperature (e.g. Valdés et al. 2007) or density (to account for freshwater inputs) in the upper $50 \mathrm{~m}$ layer. Dissolved nutrients were measured in water samples collected along with those for chlorophyll and primary production using flowsegmented colorimetric analysis (Casas et al. 1997, Llope et al. 2007). In the present study, we employed mean annual values for nitrate, phosphate and total reactive silica integrated in the water column at each station to the same depths as for chlorophyll and primary production. Annual means for the series were computed using 8 or more monthly observations for a given year. Missing values were estimated using linear interpolation.

The variability of the time series (X) was investigated using an additive decomposition method (e.g. Nogueira et al. 1998):

$$
\mathrm{X}=\overline{\mathrm{X}}+\mathrm{bt}+\mathrm{a}+\Sigma \mathrm{A}_{\mathrm{i}} \cos \left[\left(2 \pi \mathrm{t} / \mathrm{T}_{\mathrm{i}}\right)+\theta_{\mathrm{i}}\right]+\phi_{\mathrm{it}}+\varepsilon_{\mathrm{t}}
$$

where the variance terms for a given series $\mathrm{X}$ in time (t) were represented by the climatological mean of the time series $(\overline{\mathrm{x}})$, the linear trend, parameterised by the slope (b) and intercept (a) of the linear regression, the periodic components $\left(A_{i}\right.$ : amplitude, $T_{i}$ : period, $\theta_{i}$ : phase), the serial dependence between consecutive time-series values parameterised by the autocorrelation coefficients $\left(\phi_{\mathrm{it}}\right)$, and the unexplained residuals $\left(\varepsilon_{\mathrm{t}}\right)$. Periodic components were extracted using Fourier analysis (Poularikas \& Seely 1991) and their significance was determined by the Fisher G-test (Swan \& Sandilands 1995). Autocorrelation terms were determined in the detrended and deseasonalised time series using Yule-Walker equations (Wei 1989). Significance of linear regression was determined by ANOVA. Correlation between phytoplankton and environmental variables was computed using the residuals obtained after timeseries decomposition. Time-series analysis was first made on the monthly-averaged values to describe differences in seasonality along with other components of variance. The long-term trends and relationships with environmental variables were computed on annual average values of the series, as trends from monthly series are largely influenced by extreme events (e.g. blooms). Annual series allowed for the study of the influence of seasonal-scale environmental variables such as upwelling or atmospheric pressure fields. 


\section{RESULTS}

\subsection{Biomass variability at regional scale}

Temporal patterns of SeaWiFS chlorophyll varied among sites (Fig. 2). In ocean areas, the main annual bloom (defined as the maximum annual concentration) occurred in spring while low concentrations prevailed for most of the year (Fig. 2a,b). Near the coast, bloom events cropped up several times a year and chlorophyll concentrations were higher in general than those in the nearby ocean. In Galicia, blooms occurred almost all year round but particularly during spring and sum-
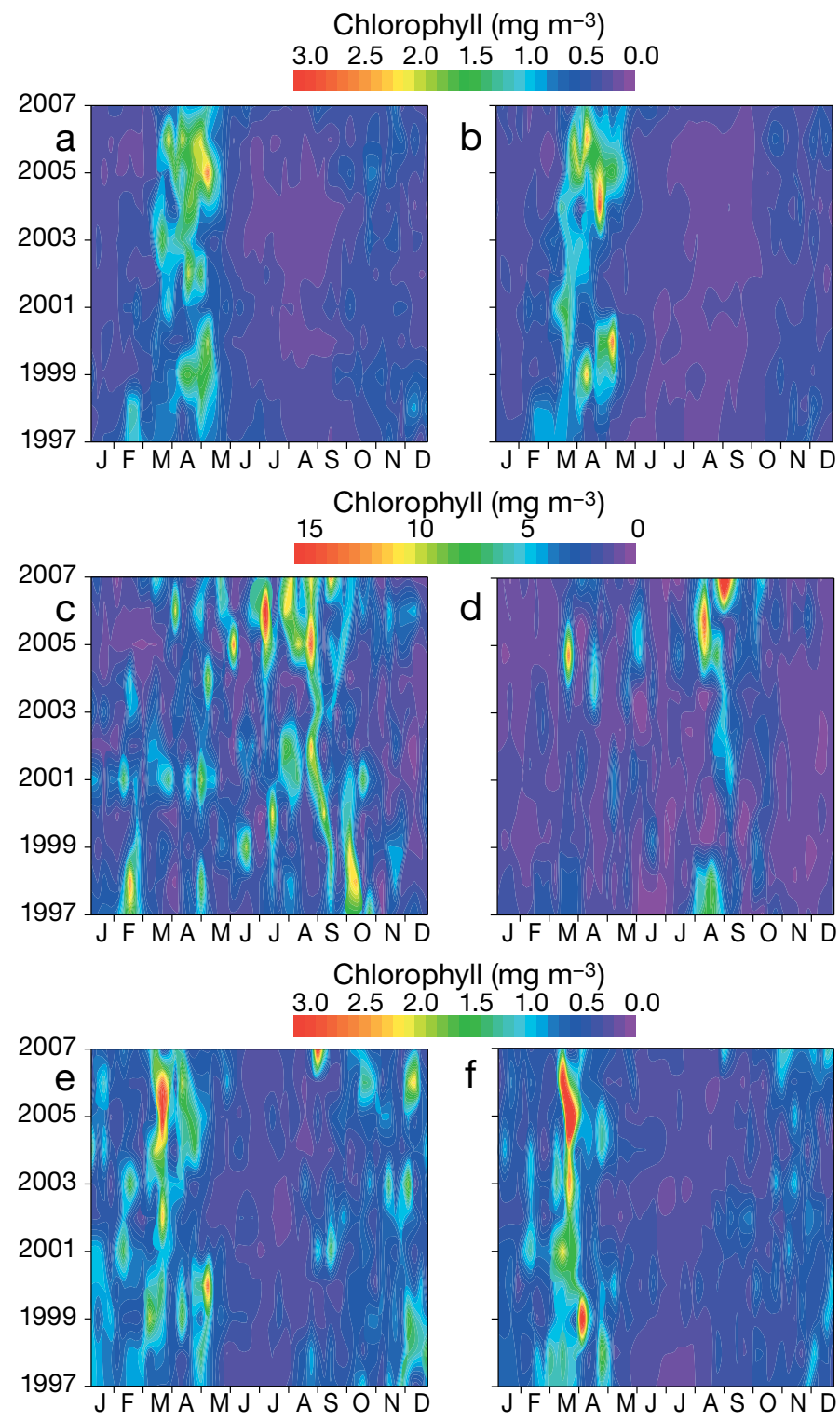

Fig. 2. Temporal variability of $8 \mathrm{~d}$ averaged SeaWiFS estimates of surface chlorophyll concentration in (a) oceanic Galicia, (b) oceanic Mar Cantábrico, (c) Vigo, (d) A Coruña, (e) Cudillero and Gijón, (f) Santander mer, the season of higher upwelling activity. Two different regimes, however, were perceptible in the Galician shelf: in the southern part there was a rapid alternance of high and low chlorophyll values (Fig. 2c); in the northern part, blooms were in general of lower magnitude, particularly during the spring (Fig. 2d). Blooms in the Mar Cantábrico were generally restricted to the spring, although some secondary blooms may appear also in autumn (Fig. 2e,f).

In situ chlorophyll series also showed short-term blooms of higher magnitude in Galicia than in the Mar Cantábrico (Fig. 3). Phytoplankton biomass concentrated generally in the surface layer except in winter and at the end of summer when water accumulation towards the coast during the upwelling-downwelling transition produced high chlorophyll values uniformly distributed through the water column (Casas et al. 1997). Local differences were apparent, despite the different lengths of the series. There was a general decreasing trend in maximum values and in the frequency of blooms from Vigo to Santander. Even over relatively short distances, there were, however, variations to these patterns. In Gijon, for instance, blooms were more frequent than in Cudillero and with a different vertical distribution.

The 2 oceanic series of SeaWiFS chlorophyll were significantly correlated $(\mathrm{r}=0.885, \mathrm{p}<0.001, \mathrm{n}=108)$, and were also correlated with those from shelf areas in the Mar Cantábrico ( $\mathrm{r}=0.669$ and 0.660 for correlation between oceanic Mar Cantábrico and Cudillero and Santander, respectively; $\mathrm{p}<0.001, \mathrm{n}=108$ ). In contrast, there were no correlations among series from the Galician shelf, nor between the latter and those series from the ocean. These relationships highlight the higher importance of coastal upwelling for phytoplankton production on the western coast compared to the northern coast, and the influence of local characteristics, such as the presence of rias. Nevertheless, all chlorophyll series from shelf areas used in the present study were significantly correlated, despite being obtained with different methods and at different sites. Correlation coefficients between SeaWiFS and in situ series were 0.593, 0.596, 0.612 and 0.602 for Vigo, A Coruña, Cudillero and Santander, respectively $(\mathrm{p}<0.001, \mathrm{n}>40)$. These results suggest that the trends in all areas were reasonably connected or consistent.

\subsection{Seasonality and long-term trends in biomass}

The analysis of SeaWiFS series averaged at monthly intervals revealed that seasonality accounted for most of the variance, particularly in off-shelf areas (Table 1). Two main peaks characterised ocean chlorophyll in both the Galicia and Mar Cantábrico areas, 
a

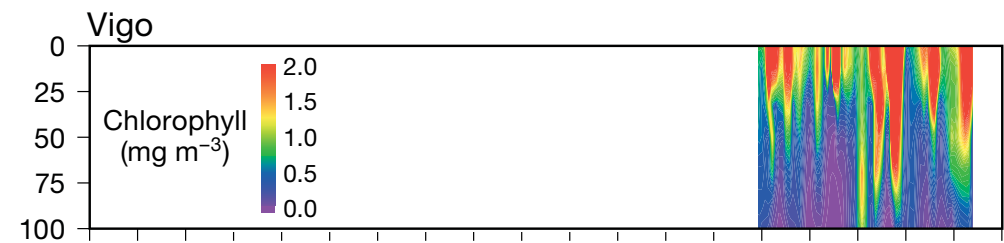

b
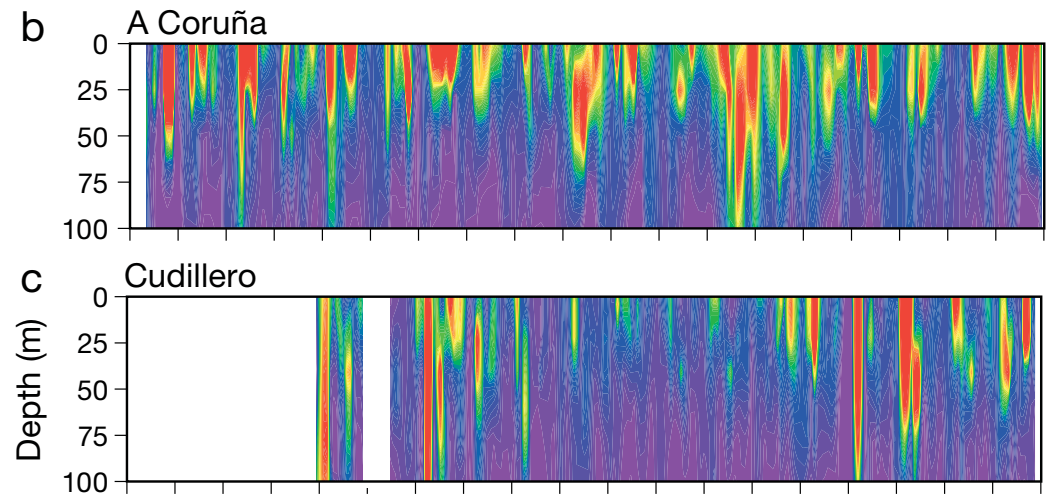

d

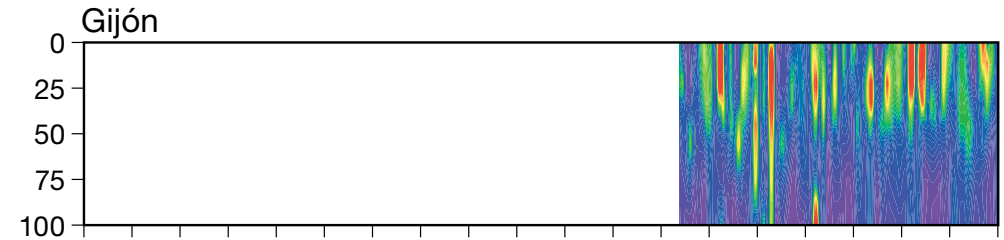

e

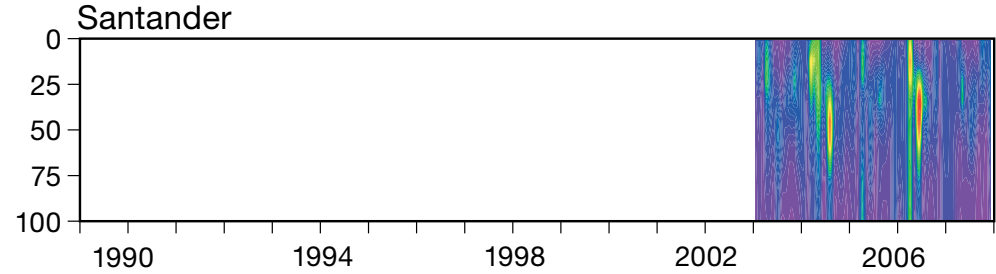

Fig. 3. Temporal and vertical variability of chlorophyll concentration measured in situ at (a) Vigo, (b) A Coruña, (c) Cudillero, (d) Gijón, (e) Santander

found only in the Galicia series, accounting for $<5 \%$ of variance, indicating that most blooms were of short duration and that correlative observations in the series were independent of each other.

There were no significant periodic components other than seasonality for any of the SeaWiFS series, indicating that there were no long-term cycles in the $10 \mathrm{yr}$ period analysed. A significant linear trend, however, appeared in the series for A Coruña, accounting for ca. $5 \%$ of total variance (Table 1). This long-term trend indicated a small but continuous increase of $0.11 \mathrm{mg} \mathrm{chl} \mathrm{m}^{-3}$ $\mathrm{yr}^{-1}$ in surface waters. Apart from this trend, the relatively low percentage of variance accounting for the time-series decomposition models indicated that, particularly in shelf waters, chlorophyll concentration was affected by local, short-term events.

\subsection{Biomass and primary production near the coast}

The longer in situ time series for chlorophyll in A Coruña and Cudillero compared to other sites, and the simultaneous measurements of primary production at these localities, allowed for a first comparative analysis of the temporal variability between Galicia and the Mar Cantábrico. As obtained from

with the largest peak being in spring and the secondary one in autumn (Fig. 4a). These peaks captured $>60 \%$ of total series variance. On the shelf, seasonality was still the main component of total variance but accounted for a lower percentage than in oceanic areas, reaching $46 \%$ in Santander (Table 1). The succession of blooms along the series affected the significance of periods found for each area (Fig. 4b). In Vigo, all blooms formed one major season of high chlorophyll concentration, extending from early spring to the autumn, while in A Coruña the blooms were grouped in 2 main peaks of equivalent concentration in spring and autumn, respectively (Fig. 4b). Similarly, in the Mar Cantábrico, the series for Cudillero revealed one main peak in early spring while in Santander there was also a secondary peak in the autumn (Fig. 4b). Other factors captured comparatively smaller fractions of total series variance rather than seasonality. Autocorrelation with 1 mo lag was the analysis of the SeaWiFS series, in situ chlorophyll and primary-production series were characterised mainly by their seasonal cycles (Table 1). In this case both series displayed a single seasonal peak (Fig. 5a) extending over most of spring and summer (A Coruña) or more centred in the spring (Cudillero). For A Coruña, the single seasonal peak obtained with the in situ series contrasts with the double peak found with the SeaWiFS series, which can be attributed to the more frequent sampling frequency of the latter (weekly), thus capturing short-living blooms in autumn (e.g. Fig. 2d). Lower sampling frequency (monthly) in the in situ series would also explain the low fraction of total variance accounted for by the models $(<20 \%)$ and the absence of autocorrelation. No significant linear trends were identified in any of the series (Table 1).

Primary production also displayed significant seasonality in both series (Fig. 5b), but in this case seasonality 
Table 1. Variance decomposition of time series of chlorophyll and primary production. Chl-SeaWiFS: SeaWiFS surface chloro-

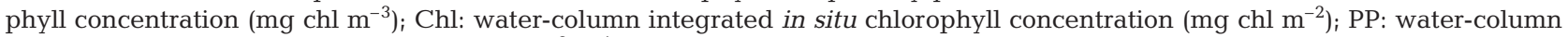
integrated primary-production rate $\left(\mathrm{mg} \mathrm{C} \mathrm{m}^{-2} \mathrm{~d}^{-1}\right)$; OG: oceanic Galicia; OC: oceanic Mar Cantábrico. Variance components: $\overline{\mathrm{x}}$ : mean; b: slope; a: intercept; $\mathrm{T}_{\mathrm{i}}$ : period; $\mathrm{A}_{\mathrm{i}}$ : amplitude; $\theta_{\mathrm{i}}$ : phase; $\mathrm{T}_{\max }$ : maximum temperature; $\Phi_{\mathrm{it}}$ : autocorrelation coefficient; $\%$ var: fraction of total variance accounted for by each component; (-): not significant $(\mathrm{p} \geq 0.05)$

\begin{tabular}{|c|c|c|c|c|c|c|c|c|c|c|c|c|c|c|}
\hline \multirow[t]{2}{*}{ Series } & \multirow[t]{2}{*}{ Period } & \multirow[t]{2}{*}{$\overline{\mathrm{x}}$} & \multicolumn{3}{|c|}{ _ Linear trend-__ } & \multicolumn{5}{|c|}{ _ Periodic components } & \multicolumn{3}{|c|}{ _-Autocorrelation- } & \multirow{2}{*}{$\begin{array}{l}\text { Total } \\
\% \text { var }\end{array}$} \\
\hline & & & $\mathrm{b}$ & a & $\%$ var & $\mathrm{T}_{\mathrm{i}}(\mathrm{mo})$ & ) $A_{i}$ & $\theta_{\mathrm{i}}$ & $\mathrm{T}_{\max }$ & \%var & Lag (mo) & $\Phi_{\text {it }}$ & $\%$ var & \\
\hline \multicolumn{15}{|c|}{ Chl-SeaWiFS } \\
\hline OG & 1998-2007 & 0.45 & - & - & - & $\begin{array}{c}12 \\
6\end{array}$ & $\begin{array}{l}0.25 \\
0.24\end{array}$ & $\begin{array}{l}4.32 \\
1.88\end{array}$ & $\begin{array}{c}3.75 \\
4.21\end{array}$ & $\begin{array}{l}33.20 \\
31.77\end{array}$ & 1 & 0.20 & 1.35 & 66.31 \\
\hline $\mathrm{OC}$ & $1998-2007$ & 0.40 & - & - & - & $\begin{array}{c}12 \\
6\end{array}$ & $\begin{array}{l}0.27 \\
0.20\end{array}$ & $\begin{array}{l}4.49 \\
2.14\end{array}$ & $\begin{array}{l}3.43 \\
3.95\end{array}$ & $\begin{array}{l}40.11 \\
21.74\end{array}$ & - & - & - & 61.85 \\
\hline Vigo & $1998-2007$ & 2.84 & & & & 12 & 0.99 & 2.31 & 7.58 & 17.20 & 1 & 0.24 & 4.64 & 21.84 \\
\hline A Coruña & 1998-2007 & 1.64 & 0.11 & -226.14 & 4.76 & 6 & 0.73 & 3.18 & 2.96 & 11.55 & 1 & 0.24 & 4.71 & 21.01 \\
\hline $\begin{array}{l}\text { Cudillero } \\
\text { and Gijón }\end{array}$ & 1998-2007 & 0.59 & - & - & - & 12 & 0.24 & 5.35 & 1.78 & 31.74 & - & - & - & 31.74 \\
\hline \multirow[t]{2}{*}{ Santander } & 1998-2007 & 0.51 & - & - & - & 12 & 0.26 & 5.07 & 2.31 & 32.71 & - & - & - & 46.23 \\
\hline & & & - & - & - & 6 & 0.17 & 2.77 & 3.36 & 13.52 & - & - & - & \\
\hline \multicolumn{15}{|l|}{ Chl } \\
\hline A Coruña & 1989-2007 & 43.44 & - & - & - & 12 & 16.48 & 3.57 & 5.18 & 16.16 & - & - & - & 16.16 \\
\hline Cudillero & $1992-2007$ & 30.65 & - & - & - & 12 & 9.91 & 4.12 & 4.13 & 11.16 & - & - & - & 11.16 \\
\hline \multicolumn{15}{|l|}{ PP } \\
\hline A Coruña & 1989-2007 & 138.07 & 4.95 & -9893.40 & 4.82 & 12 & 87.22 & 3.44 & 5.43 & 24.40 & - & - & - & 29.22 \\
\hline Cudillero & $1992-2007$ & 82.84 & -4.11 & 8210.40 & 6.72 & 12 & 34.51 & 3.74 & 4.86 & 11.33 & - & - & - & 30.36 \\
\hline
\end{tabular}
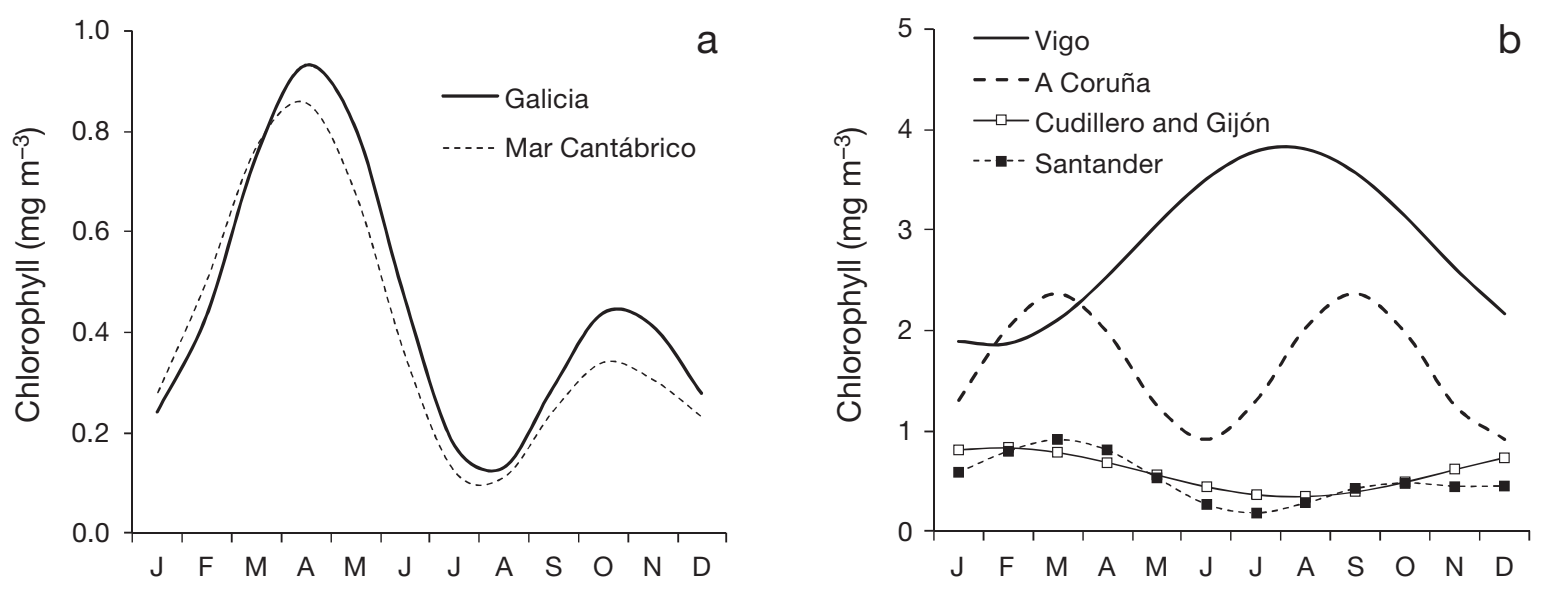

Fig. 4. Seasonality of SeaWiFS estimates of surface chlorophyll concentration in (a) oceanic areas of Galicia and Mar Cantábrico, (b) coastal areas

accounted for ca. $30 \%$ of total variance (Table 1). In contrast, chlorophyll in the series of A Coruña displayed a significant linear long-term positive trend, while the series of Cudillero showed a negative trend. Both trends were of similar magnitude (between 4 and $5 \mathrm{mg} \mathrm{C} \mathrm{m}^{-2} \mathrm{~d}^{-1} \mathrm{yr}^{-1}$ ) and accounted for 5 to $7 \%$ of total variance, but differed in sign (positive or negative values) (Table 1).

\subsection{Long-term trends and environmental changes}

The annually-averaged series followed trends similar to those described using the monthly-averaged series. As indicated in Section 3.3, no significant long-term cycles were found and the only significant component identified was the linear trend for primary production at A Coruña (Table 2). This positive 

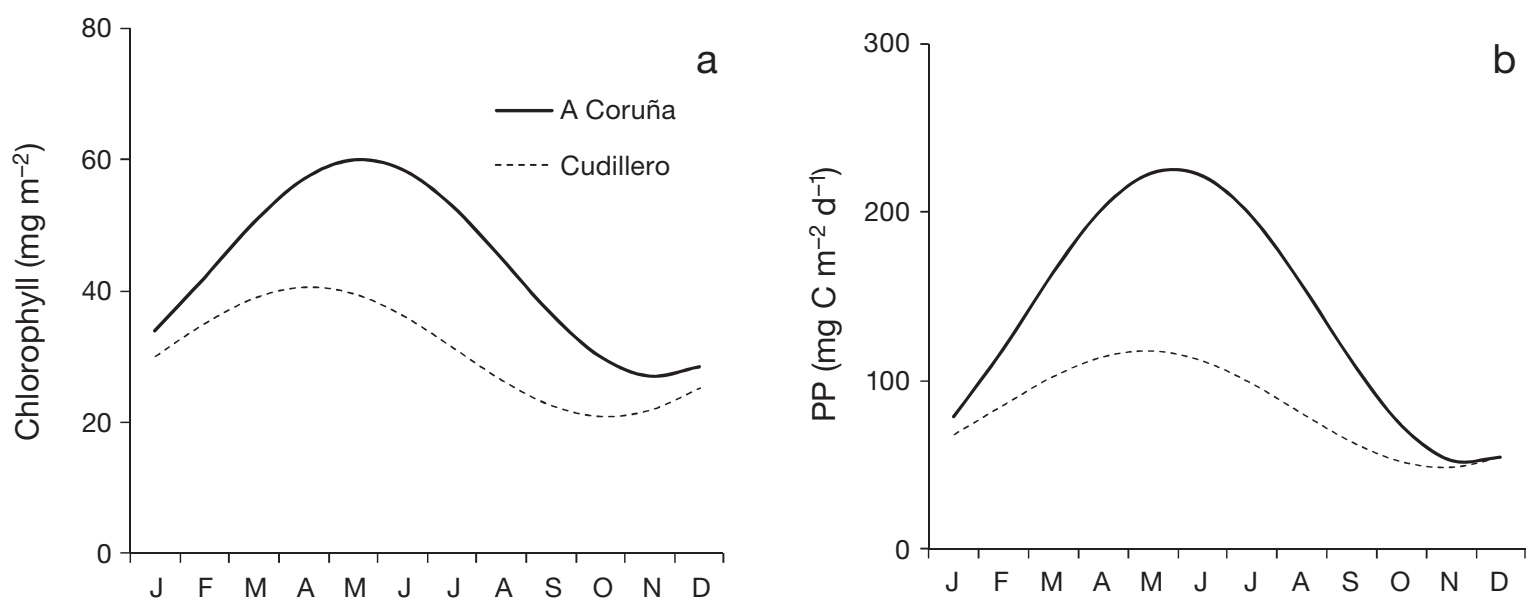

Fig. 5. Seasonality of water-column integrated (a) chlorophyll and (b) primary production (PP) measured in situ in A Coruña and Cudillero

Table 2. Significant $(p<0.05)$ interannual trends indicated by the parameters of the linear regression between the sampling year and annual mean values of chlorophyll concentration $\left(\mathrm{Chl}, \mathrm{mg} \mathrm{m}^{-2}\right)$, primary-production rate $\left(\mathrm{PP}, \mathrm{mg} \mathrm{C} \mathrm{m}^{-2}\right.$ $\left.\mathrm{d}^{-1}\right)$, nitrate concentration $\left(\mathrm{N}, \mathrm{mmol} \mathrm{\textrm {m } ^ { - 2 }}\right)$, phosphate concentration $(\mathrm{P}, \mathrm{mmol}$ $\left.\mathrm{m}^{-2}\right)$, silicate concentration $\left(\mathrm{Si}_{1} \mathrm{mmol} \mathrm{m}^{-2}\right)$, nitrate-to-phosphate $(\mathrm{N}: \mathrm{P})$ and nitrate-to-silicate (N:Si) ratios, sea surface temperature (SST), standard deviation of temperature $\left(\mathrm{sd} t,{ }^{\circ} \mathrm{C}\right)$ and standard deviation of density $\left(\mathrm{sd} \sigma_{\mathrm{t}}\right)$. All variables except SST were integrated or averaged in the photic layer of A Coruña $(40 \mathrm{~m})$ and Cudillero $(50 \mathrm{~m})$ stations. Significant linear trends are for the North Atlantic Oscillation averaged between December and March $\left(\mathrm{NAO}_{\mathrm{DM}}\right)$ or between June and August $\left(\mathrm{NAO}_{\mathrm{JJA}}\right)$, for the annual average of the Atlantic Multidecadal Oscillation (AMO) and for the upwelling index $\left(\mathrm{UI}_{\mathrm{AS}}\right)$ computed in a $2^{\circ} \times 2^{\circ}$ cell centred at $43^{\circ} \mathrm{N}, 11^{\circ} \mathrm{W}$ and averaged between April and September. b: slope, a: in tercept, \%var: percent of total variance accounted for by the regression, r: correlation coefficient, p: significance; (-): not significant

\begin{tabular}{|c|c|c|c|c|c|c|c|}
\hline Variable & Zone & Period & $\mathrm{b}$ & a & $\%$ var & $\mathrm{r}$ & $\mathrm{p}$ \\
\hline Chl & $\begin{array}{l}\text { A Coruña } \\
\text { Cudillero }\end{array}$ & $\begin{array}{l}1989-2007 \\
1993-2007\end{array}$ & $\begin{array}{l}- \\
-\end{array}$ & $\begin{array}{l}- \\
-\end{array}$ & $\begin{array}{l}- \\
-\end{array}$ & $\begin{array}{l}- \\
-\end{array}$ & $\begin{array}{l}- \\
-\end{array}$ \\
\hline PP & $\begin{array}{l}\text { A Coruña } \\
\text { Cudillero }\end{array}$ & $\begin{array}{l}1990-2007 \\
1993-2007\end{array}$ & $\begin{array}{c}13.71 \\
-\end{array}$ & $\begin{array}{c}-27397.30 \\
-\end{array}$ & $\begin{array}{c}60.89 \\
-\end{array}$ & $\begin{array}{c}0.780 \\
-\end{array}$ & $\begin{array}{c}<0.001 \\
-\end{array}$ \\
\hline SST & $\begin{array}{l}\text { A Coruña } \\
\text { Cudillero }\end{array}$ & $\begin{array}{l}1989-2006 \\
1989-2006\end{array}$ & $\begin{array}{c}0.03 \\
-\end{array}$ & $\begin{array}{c}-59.74 \\
-\end{array}$ & $\begin{array}{c}23.23 \\
-\end{array}$ & $\begin{array}{c}0.482 \\
-\end{array}$ & $\begin{array}{c}0.043 \\
-\end{array}$ \\
\hline$s d t$ & $\begin{array}{l}\text { A Coruña } \\
\text { Cudillero }\end{array}$ & $\begin{array}{l}1991-2007 \\
1993-2007\end{array}$ & $\begin{array}{l}- \\
-\end{array}$ & $\begin{array}{l}- \\
-\end{array}$ & $\begin{array}{l}- \\
-\end{array}$ & $\begin{array}{l}- \\
-\end{array}$ & $\begin{array}{l}- \\
-\end{array}$ \\
\hline $\mathrm{sd} \sigma_{\mathrm{t}}$ & $\begin{array}{l}\text { A Coruña } \\
\text { Cudillero }\end{array}$ & $\begin{array}{l}1991-2007 \\
1993-2007\end{array}$ & $\begin{array}{c}0.01 \\
-\end{array}$ & $\begin{array}{c}-19.14 \\
-\end{array}$ & $\begin{array}{c}44.69 \\
-\end{array}$ & $\begin{array}{c}0.669 \\
-\end{array}$ & $\begin{array}{l}0.003 \\
-\end{array}$ \\
\hline $\mathrm{N}$ & $\begin{array}{l}\text { A Coruña } \\
\text { Cudillero }\end{array}$ & $\begin{array}{l}1989-2007 \\
1993-2007\end{array}$ & $\begin{array}{l}- \\
-\end{array}$ & $\begin{array}{l}- \\
-\end{array}$ & $\begin{array}{l}- \\
-\end{array}$ & $\begin{array}{l}- \\
-\end{array}$ & - \\
\hline $\mathrm{P}$ & $\begin{array}{l}\text { A Coruña } \\
\text { Cudillero }\end{array}$ & $\begin{array}{l}1989-2007 \\
1993-2007\end{array}$ & $\begin{array}{l}- \\
-\end{array}$ & $\begin{array}{l}- \\
-\end{array}$ & $\begin{array}{l}- \\
-\end{array}$ & $\begin{array}{l}- \\
-\end{array}$ & $\begin{array}{l}- \\
-\end{array}$ \\
\hline $\mathrm{Si}$ & $\begin{array}{l}\text { A Coruña } \\
\text { Cudillero }\end{array}$ & $\begin{array}{l}1991-2007 \\
1993-2007\end{array}$ & $\begin{array}{c}3.31 \\
-\end{array}$ & $\begin{array}{c}-6616.08 \\
-\end{array}$ & $\begin{array}{c}37.60 \\
-\end{array}$ & $\begin{array}{c}0.613 \\
-\end{array}$ & $\begin{array}{c}0.009 \\
-\end{array}$ \\
\hline $\mathrm{N}: \mathrm{P}$ & $\begin{array}{l}\text { A Coruña } \\
\text { Cudillero }\end{array}$ & $\begin{array}{l}1989-2007 \\
1993-2007\end{array}$ & $\begin{array}{l}- \\
-\end{array}$ & $\begin{array}{l}- \\
-\end{array}$ & $\begin{array}{l}- \\
-\end{array}$ & $\begin{array}{l}- \\
-\end{array}$ & $\begin{array}{l}- \\
-\end{array}$ \\
\hline $\mathrm{N}: \mathrm{Si}$ & $\begin{array}{l}\text { A Coruña } \\
\text { Cudillero }\end{array}$ & $\begin{array}{l}1991-2007 \\
1993-2007\end{array}$ & $\begin{array}{r}-0.09 \\
0.05\end{array}$ & $\begin{array}{l}184.19 \\
-93.18\end{array}$ & $\begin{array}{l}24.84 \\
29.55\end{array}$ & $\begin{array}{r}-0.498 \\
0.544\end{array}$ & $\begin{array}{l}0.042 \\
0.036\end{array}$ \\
\hline $\mathrm{NAO}_{\mathrm{DM}}$ & & $1989-2007$ & -0.04 & 85.21 & 28.28 & -0.532 & 0.019 \\
\hline $\mathrm{NAO}_{\text {JJA }}$ & & $1989-2007$ & - & - & - & - & - \\
\hline $\mathrm{AMO}$ & & $1989-2007$ & 0.02 & -48.76 & 58.30 & 0.764 & $<0.001$ \\
\hline $\mathrm{UI}_{\mathrm{AS}}$ & & $1989-2007$ & -10.18 & 20339.99 & 23.54 & -0.485 & 0.035 \\
\hline
\end{tabular}

trend was highly significant and accounted for $60 \%$ of total variance of the series. An apparent decadal cycle, however, is indicated by the distribution of values for both chlorophyll and primary-production series in Cudillero (Fig. 6). This cycle is characterised by high values in the early 1990 s and late 2000 s, with relatively low values between 1995 and 2002 for chlorophyll and between 1996 and 2005 for production. That some years lacked enough observations, and that the series was relatively short (16 yr), may have caused the multiyear cycle or trend to be not significant in our analysis.

The main significant component of the annual series of environmental variables was the linear trend (Table 2). In the case of phosphate concentrations and the $\mathrm{N}: \mathrm{P}$ ratio in $\mathrm{A}$ Coruña, there was a significant cycle of $18 \mathrm{yr}$ accounting for ca. $60 \%$ of total variance. The amplitude and phase of these cycles was 4.97 and 0.25 , respectively for phosphate (65.7\% variance), and 10.77 and 3.43 for the N:P ratio (56.3\% variance). Warming of surface waters was signif-

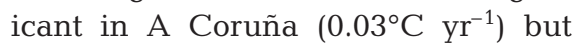
not in Cudillero, and mainly originated from the low values measured in 1990 in A Coruña (Fig. 7a). Stratification measured by the vertical variability in temperature did not show 

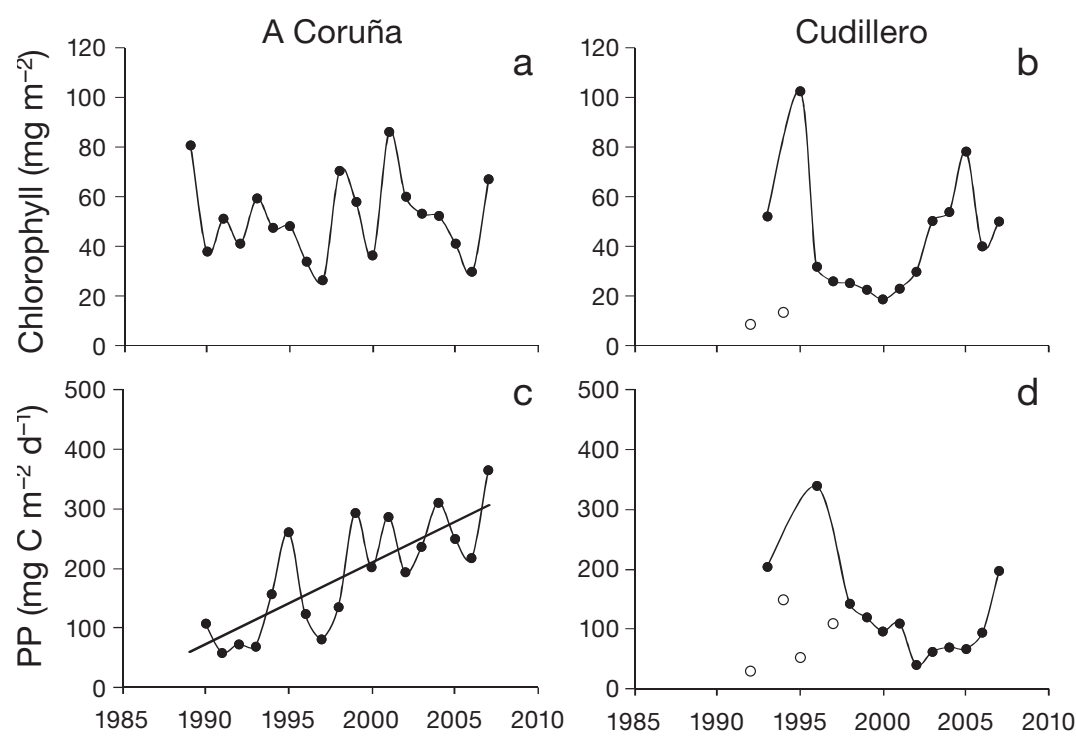

Fig. 6. Temporal variability of annual mean values of water-column integrated $(\mathrm{a}, \mathrm{b})$ chlorophyll and $(\mathrm{c}, \mathrm{d})$ primary production $(\mathrm{PP})$ measured in situ in $(\mathrm{a}, \mathrm{c}) \mathrm{A}$ Coruña and (b,d) Cudillero. Mean values computed using $<8$ monthly observations $(O)$ were not used in the series analysis. Straight line: significant trend (see Table 2)

any significant trend in either series (Fig. 7b), while there was a positive trend in the vertical variability of $\sigma_{\mathrm{t}}$ in A Coruña (Fig. 7c). Dissolved nutrients did not show linear interannual trends, except for an increase in silicate concentration in A Coruña (Fig. 8). The distribution of nutrient values suggests the presence of large cycles in several cases, such as the significant 18 yr cycle for phosphate (Fig. 8b) in A Coruña accompanied by similar (but non-significant) variations in phosphate and nitrate concentrations in Cudillero. The trends in large-scale variables were negative for NAO and UI and positive for AMO during the study period (Fig. 9, Table 2). same year. Thermal stratification was negatively correlated with primary production (but not with chlorophyll) with a lag of 2 yr. The effect of NAO conditions during the previous winter was positive on primary production at A Coruña, while there were no significant correlations between phytoplankton variables and summer NAO. In contrast, there were no significant correlations between stratification or largescale variables and primary production at Cudillero. The only significant correlations where those of nutrient ratios $\mathrm{N}: \mathrm{P}$ and $\mathrm{N}: \mathrm{Si}$ from the same year or from the year before the primary-production values were averaged.
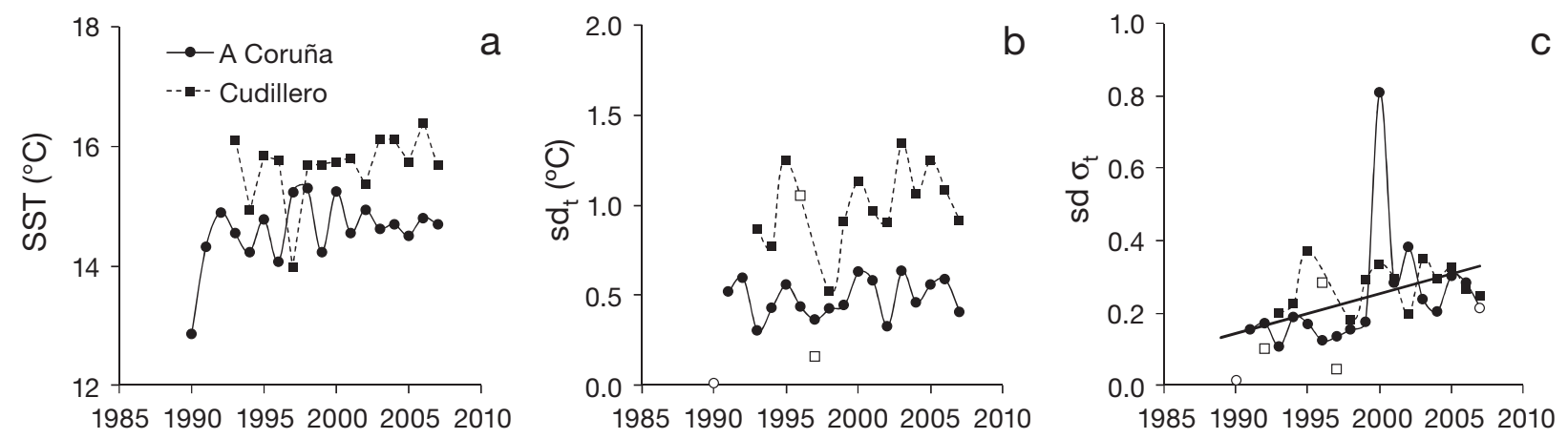

Fig. 7. Temporal variability of annual mean values of (a) sea surface temperature (SST) and 2 indices of stratification: (b) the SD of temperature $\left(\mathrm{sd}_{\mathrm{t}}\right)$ and $(\mathrm{c})$ that of density $\left(\mathrm{sd}_{\mathrm{t}}\right)$ between 0 and $40 \mathrm{~m}$ depth in A Coruña and Cudillero. Open symbols: mean values computed using < 8 monthly observations that were not used in the series analysis. Straight line: significant trend (see Table 2) 

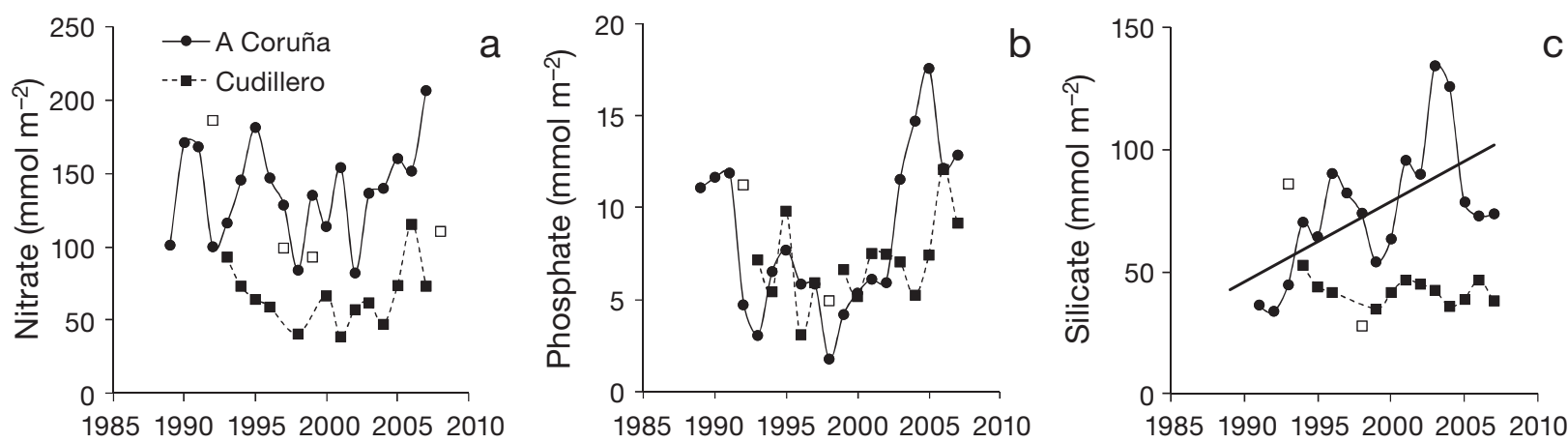

Fig. 8. Temporal variability of annual mean values of (a) nitrate, (b) phosphate and (c) silicate integrated in the water column in A Coruña and Cudillero. Open symbols: mean values computed using $<8$ monthly observations that were not used in the series analysis. Straight line: significant trend (see Table 2)
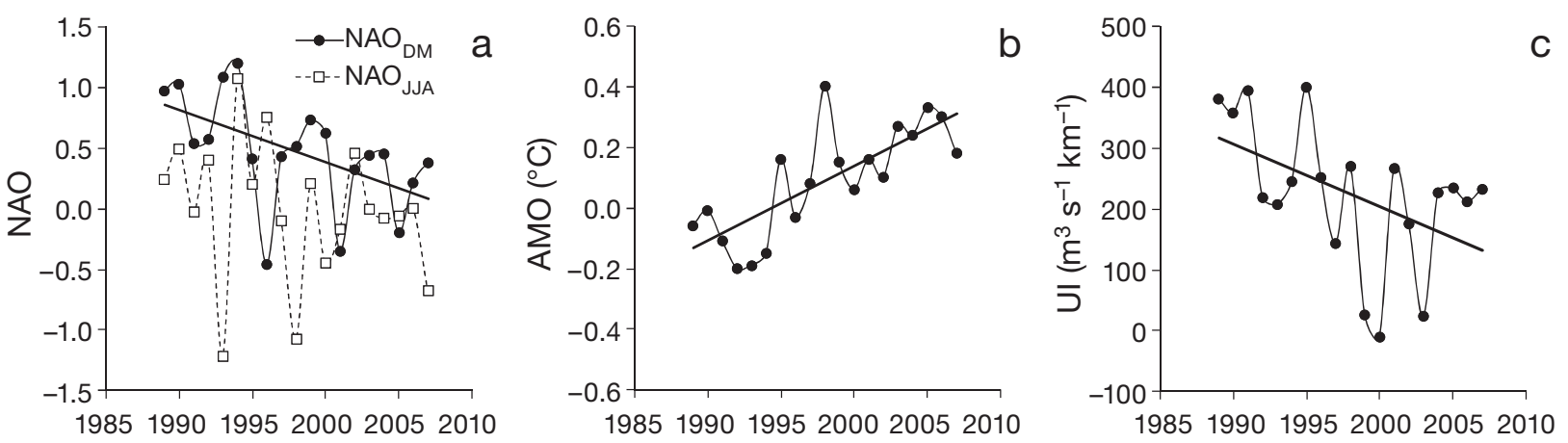

Fig. 9. Temporal variability of annual mean values of large-scale, climatic variables: (a) North Atlantic Oscillation (NAO) index averaged between December and March (DM) or between June and August (JJA), (b) Atlantic Multidecadal Oscillation (AMO), (c) Upwelling Index (UI) computed from geostrophic winds in a $2^{\circ} \times 2^{\circ}$ cell centred at $43^{\circ} \mathrm{N}, 11^{\circ} \mathrm{W}$. Straight lines: significant trends (see Table 2)

Table 3. Significant $(p<0.05)$ cross-correlations between annual mean values of chlorophyll $\left(\mathrm{Chl}, \mathrm{mg} \mathrm{m}^{-2}\right)$ or primary production ( $\mathrm{PP}, \mathrm{mg} \mathrm{C} \mathrm{m}^{-2} \mathrm{~d}^{-1}$ ) and environmental variables in Table 2. See Table 2 for abbreviations. Only correlations delayed up to 2 yr were considered; (-): not significant

\begin{tabular}{|lcccccc|}
\hline \multirow{2}{*}{ Variable } & \multirow{2}{*}{ Series } & \multicolumn{2}{c}{ Chl } & \multicolumn{2}{c|}{ PP } \\
& & r & Lag $(\mathrm{yr})$ & r & Lag $(\mathrm{yr})$ \\
\hline $\mathrm{SST}$ & None & - & - & - & - \\
$\mathrm{sd} \mathrm{t}$ & A Coruña & - & - & -0.489 & 2 \\
& Cudillero & 0.575 & 0 & - & - \\
$\mathrm{sd} \sigma_{\mathrm{t}}$ & None & - & - & - & - \\
$\mathrm{N}$ & A Coruña & - & - & 0.514 & 0 \\
$\mathrm{P}$ & A Coruña & -0.498 & 1 & - & - \\
$\mathrm{Si}$ & None & - & - & - & - \\
$\mathrm{N}: \mathrm{P}$ & A Coruña & 0.620 & 0 & - & - \\
& Cudillero & - & - & 0.680 & 0 \\
$\mathrm{~N}: \mathrm{Si}$ & Cudillero & - & - & 0.634 & 1 \\
$\mathrm{NAO}$ & A Coruña & - & - & 0.677 & 1 \\
$\mathrm{NAO}_{\text {JJA }}$ & None & - & - & - & - \\
$\mathrm{AMO}$ & None & - & - & - & - \\
$\mathrm{UI}_{\mathrm{AS}}$ & Cudillero & 0.572 & 0 & - & - \\
\hline
\end{tabular}

\section{DISCUSSION}

\subsection{Seasonal cycle of phytoplankton biomass and production}

Our analysis using the longest time-series observations for the northern Iberian coast to date, spanning $>15 \mathrm{yr}$, revealed a marked gradient in the seasonality of phytoplankton biomass and primary production related to the prevalence of upwelling. Previous studies using shorter series highlighted some local characteristics, such as the fertilising effect of upwelling (e.g. Bode et al. 1996), but the emphasis was generally on the seasonal cycle of a main spring bloom and a secondary bloom in autumn, which is expected for a temperate sea (e.g. Longhurst 2007). The present study shows that blooms occur during a longer season and are of higher intensity and frequency on the western coast (Galicia) compared to the northern coast (Mar Cantábrico). Furthermore, the intensity of blooms decreased from south to north along the Galician coast, as the presence of large rias in southern Galicia amplify the fertilising effect of upwelling by regenerat- 
ing the organic matter initially synthesised from new nutrients (Álvarez-Salgado et al. 2002). In areas with small rias, such as A Coruña, there is less amplification of upwelling nutrients because of limited nutrient regeneration (Bode et al. 2004) and, therefore, biomass and production values may be smaller than in Vigo. In the Mar Cantábrico, where upwelling is restricted to occasional events during summer (Botas et al. 1990), maximum values of biomass and production are lower than in Galicia and decrease from west to east. These variations produce clearly different average seasonal cycles for both subregions, even though we must assume that there are limitations to extrapolating the conditions at single sites as being representative of Galicia and Mar Cantábrico. Phytoplankton in Galicia displays a unique, extended high-biomass season extending from early spring through autumn, while in the easternmost areas of the Mar Cantábrico, and in off-shelf areas where the influence of upwelling is small, there is a major spring bloom and a secondary one in the autumn. The average seasonal cycle for primary production is similar to that of biomass (Fig. 5).

The present analysis highlights the importance of seasonality for oceanic and shelf areas in the Mar Cantábrico, where this factor accounted for a large percentage of total variance, while for shelf areas in Galicia, seasonality was of lower importance compared to other factors, such as upwelling pulses. Besides seasonality, the general lack of significant systematic factors, such as multiyear cycles, linear trends or autocorrelation, supports the dominant role of local high-frequency events affecting the observed chlorophyll concentrations near the coast in Galicia. Removal of seasonality and high-frequency variability is thus justified before analysis of long-term trends in biomass and primaryproduction series in the study region.

\subsection{Multiyear trends in biomass and production}

No clear linear trends were found for the series of phytoplankton biomass. The apparent increase in surface chlorophyll observed in the SeaWiFS series of A Coruña using monthly-averaged values was not evident when using annual averages. Analysis of other series also led us to conclude that biomass values did not follow any significant long-term trend. Previous studies using biomass estimates from the phytoplankton colour index (PCI) derived from the Continuous Plankton Recorder (CPR) suggested an apparent increase in phytoplankton biomass in the whole eastern Atlantic region (Leterme et al. 2005). However, recent studies using the same CPR data but for a region close to Galicia between 1958 and 2006 did not show signifi- cant trends, although values for the period 1997 to 2006 were in general lower than those recorded earlier in the series (Bode et al. 2009).

Trends in primary production were also dependent on the time period used for averaging the values. The apparent long-term decrease computed for the series in Cudillero was not significant when using annuallyaveraged values, and the time distribution of values suggested a decadal cycle (Fig. 6). Similar conclusions were reached by Llope et al. (2007) when analysing a shorter version of the same series. Only the systematic increase in primary production values observed at A Coruña was significant using both monthly and yearly series. This result contrasts with the expected decrease in new production in Galician shelf waters as predicted from models based on the intensity of upwelling (Pérez et al. 2010). New production, however, refers only to primary production based on nutrients provided by upwelling, which decreased in this region during the last $40 \mathrm{yr}$. The experimentally measured primary production rates in the present study are estimates of total rather than new production, as they account for both new and regenerated nutrients (Bode et al. 2004). The non-significant changes or even the increases observed in total primary production could be the consequence of an increase in the input of regenerated nutrients, as found in the case of waters inside the rias (Pérez et al. 2010).

\subsection{Oceanographic and climatic influence on biomass and production}

Changes in irradiance, temperature or nutrient availability are among the key factors regulating phytoplankton production. Irradiance in the sea is determined by the seasonal solar cycle; large year-to-year variations are unlikely. An examination of the series of photosynthetically active radiation measurements obtained at A Coruña with hourly frequency during the study period did not reveal any significant long-term trend (data not shown), and the same occurred with water transparency at the sampling locations, as indicated by the depth distribution of chlorophyll (Fig. 3). Temperature was not a relevant variable related to either chlorophyll or primary-production values at interannual scales, as indicated by the cross-correlation analysis. Although we did not detect a consistent and significant increase in water temperature (Fig. 7), other studies have detected a measurable warming of the surface and even subsurface layers in the study region during the last few decades (González-Pola et al. 2005, Pérez et al. 2010), corresponding to a positive anomaly phase of the AMO (Delworth \& Mann 2000). Therefore, nutrient availability appears to be one of 
the main factors responsible for the observed changes.

Both individual nutrients, such as phosphate, and nutrient ratios showed correlations with primary production and biomass. That the correlations were positive is consistent with the expected direct effect of nutrients on phytoplankton, particularly in upwellingdriven ecosystems (e.g. Nogueira et al. 1998). Differences in the statistical significance when either chlorophyll or primary production were analysed can be related to the different time-integration periods of phytoplankton production represented by each variable. The observed chlorophyll concentration at any given date is the result of both production and loss processes, the latter including grazing and sedimentation. In contrast, our measurements of primary production represent more closely the gross uptake of inorganic carbon at scales of hours and therefore should better reflect the effects of nutrients on the synthesis of organic carbon. Interestingly, the variations in production were more clearly related to nutrient ratios than to individual nutrients, as indicated by the absolute value of the cross-correlation coefficients (Table 3). Previous studies in the Cudillero series noted the relationship between the N:P ratio and the species composition of the phytoplankton community at decadal scales (Llope et al. 2007), but similar changes were also observed in the Alborán upwelling system in the Mediterranean (Mercado et al. 2007). Changes in nutrient proportions are indicative of changes in the origin of water masses. Periods of high and low upwelling intensity are known to influence both the absolute and relative nutrient concentrations of surface waters, and the effects propagate up the food web (Rau et al. 2003).

The current phase of upwelling in the study region is of decreasing intensity and duration of the favourable period during the last few decades (Lemos \& Sansó 2006). This region behaves in the opposite direction compared to major upwelling systems, where upwelling-favourable wind is increasing and water temperature is decreasing (Mendelssohn \& Schwing 2002, McGregor et al. 2007). Its marginal location in relation to the main atmospheric pressure fields causes the southern displacement of high pressure over the northern Atlantic, as indicated by negative phases of the NAO (Barnston \& Livezey 1987), so that southerlies decrease in Galicia and Portugal (Lemos \& Sansó 2006) while they increase in northern Africa (McGregor et al. 2007). The weakened upwelling is related to decreases in coastal nutrients in areas where in situ regeneration is limited (Mercado et al. 2007), but in Galicia, remineralisation of organic matter enhances the effect of upwelling on primary production (Bode et al. 2004). Recirculation of bottom shelf waters, loaded with nutrients regenerated from the organic matter produced in the surface, may increase the level of expected nutri- ents during phases of low upwelling (Pérez et al. 2010), as found in the present study. Moreover, the multidecadal cycle suggested for phosphate variability, with maximum values at both ends of the series, is indicative of a change in the origin of the upwelled waters. Higher nutrient content is associated with Eastern North Atlantic Central Waters (ENACW) of subpolar rather than subtropìcal origin, and the variability of this water mass in the region is related to atmospheric forcing in winter at the formation area and advection of western waters (van Aken 2001). Therefore the dominant type of ENACW upwelled in a particular year would affect nutrient availability for phytoplankton production. Subtropical ENACW is associated with poleward-flowing slope currents, higher in years with low NAO (Garcia-Soto et al. 2002), and its nutrient content increases during its displacement along the Galician coast (Álvarez-Salgado et al. 2003) but decreases in the Mar Cantábrico (Bode et al. 2002). High nutrient inputs, such as those found in 2005 in the present study, may result from deep mixing of the water column during extremely cold winters, which reduced the stratification of the upper layers for several years (Somavilla et al. 2009).

In contrast with the open ocean, shelf waters in NW Spain have not developed strong stratification as a consequence of surface warming, and therefore nutrient inputs and phytoplankton production and biomass were not generally reduced. Indeed, increased stratification can enhance phytoplankton biomass by limiting mixing of phytoplankton out of the euphotic zone, as indicated by the positive correlation between thermal stratification and chlorophyll in Cudillero. Thermal stratification, however, was more pronounced to the east of the Mar Cantábrico, where upwelling events were rare (Valdés et al. 2007). The decrease in upwelling, along with high inputs of freshwater by runoff during years of high precipitation, as was recorded in 2000 (Bode et al. 2005), contributed to a long-term increasing trend in density stratification in A Coruña. The negative effects on primary production, albeit significant, were delayed for several years and did not affect the long-term increase in Galicia. In the Mar Cantábrico, the positive correlation between thermal stratification and chlorophyll indicated that stratification favoured the accumulation of phytoplankton biomass. Such effects indicate that the present stratification of shelf and coastal waters is not strong enough to limit primary production, and even enhances the input of remineralised nutrients (Pérez et al. 2010). Observations of large marine ecosystems in ocean shelves using SeaWiFS series also showed no significant changes or even increases in phytoplankton biomass and primary production, despite significant warming of surface waters (Sherman \& Hempel 2009). 
Nutrient inputs by winter mixing, summer upwelling, freshwater runoff or in situ remineralisation depend ultimately on atmospheric forcing, such as drivers of heat exchanges and precipitation (Somavilla et al. 2009), or coastal currents (Álvarez-Salgado et al. 2003). Nevertheless, direct correlations between large-scale climatic indices, such as the NAO, and plankton variables in this region are generally weak or lagged for relatively long periods (Planque et al. 2003, Bode et al. 2009), while there are stronger relationships in northern regions (e.g. Beaugrand et al. 2000). The pelagic ecosystem on the NW Spanish shelf displays a high within-year variability, due in part to upwelling events. This variability contrasts with the seasonal variability of boreal ecosystems characterised by an intense spring plankton bloom of relatively short duration and high stratification and low plankton production for most of the year. In the latter case, the winter NAO index accurately reflects the conditions leading to nutrient enrichment and therefore plankton production in the surface layers of the ocean as well as precipitation and winds over continental Europe (Barnston \& Livezey 1987). Monthly or summer-averaged NAO index values are more directly related to upwelling conditions in Galicia (Pérez et al. 2010), but the use of this index did not increase correlations with either chlorophyll or production series in the present study.

Recent decadal changes in primary production on the NW shelf of Spain differ from those observed in the nearby ocean mainly because of nutrient inputs, which did not decrease despite a reduction in upwelling intensity (Fig. 8). Increasing dependence on nutrients remineralised from previous organic-matter synthesis near the coast may explain the small impact of warming of the surface ocean in Galicia, while apparent cyclic oscillations in primary production in the Mar Cantabrico would be related to changes in the formation of water masses during winter. The observed changes in primary production are transmitted up the food web in the form of long-term increases of zooplankton biomass in Galicia and decreases in the Mar Cantábrico (Bode et al. 2009).

Acknowledgements. This study would have not been possible without the dedication of a large number of technicians, crew members and scientists who contributed to the observational time series. We are grateful to G. González-Nuevo for providing the software (Time-Series Toolkit) and assistance for the statistical analysis. The final version of the manuscript benefited from the detailed comments and suggestions of 2 anonymous referees. SeaWiFS data were obtained from the GES-DISC Interactive Online Visualization ANd aNalysis Infrastructure (Giovanni) of the NASA's Goddard Earth Sciences Data and Information Services Center. This research was funded in part by projects RADIALES (IEO), REFORZA (PGIDIT06RMA60401PR), HERCULES (09MMA027604PR) and ANILE (CTM2009-08396). This is contribution number 292 to the RADIALES project.

\section{LITERATURE CITED}

Álvarez-Salgado XA, Beloso S, Joint I, Nogueira E and others (2002) New production of the NW Iberian shelf during the upwelling season over the period 1982-1999. Deep-Sea Res I 49:1725-1739

Álvarez-Salgado XA, Figueiras FG, Pérez FF, Groom S and others (2003) The Portugal coastal counter current off NW Spain: new insights on its biogeochemical variability. Prog Oceanogr 56:281-321

> Bakun A (1990) Global climate change and intensification of coastal upwelling. Science 247:198-201

- Barnston AG, Livezey RE (1987) Classification, seasonality and persistence of low-frequency atmospheric circulation patterns. Mon Weather Rev 115:1083-1126

> Beaugrand G, Ibanez F, Reid PC (2000) Spatial, seasonal and long-term fluctuations of plankton in relation to hydroclimatic features in the English Channel, Celtic Sea and Bay of Biscay. Mar Ecol Prog Ser 200:93-102

> Behrenfeld MJ, O'Malley RT, Siegel DA, McClain CL and others (2006) Climate-driven trends in contemporary ocean productivity. Nature 444:752-755

> Bode A, Casas B, Fernández E, Marañón E, Serret P, Varela M (1996) Phytoplankton biomass and production in shelf waters off NW Spain: spatial and seasonal variability in relation to upwelling. Hydrobiologia 341:225-234

Bode A, Varela M, Casas B, González N (2002) Intrusions of eastern North Atlantic central waters and phytoplankton in the north and northwestern Iberian shelf during spring. J Mar Syst 36:197-218

Bode A, Barquero S, González N, Alvarez-Ossorio MT, Varela M (2004) Contribution of heterotrophic plankton to nitrogen regeneration in the upwelling ecosystem of A Coruña (NW Spain). J Plankton Res 26:11-28

Bode A, González N, Rodríguez C, Varela M, Varela MM (2005) Seasonal variability of plankton blooms in the Ria de Ferrol (NW Spain). I. Nutrient concentrations and nitrogen uptake rates. Estuar Coast Shelf Sci 63:269-284

- Bode A, Alvarez-Ossorio MT, Cabanas JM, Miranda A, Varela M (2009) Recent trends in plankton and upwelling intensity off Galicia (NW Spain). Prog Oceanogr 83: 342-350

Botas JA, Fernández E, Bode A, Anadón R (1990) A persistent upwelling off the Central Cantabrian Coast (Bay of Biscay). Estuar Coast Shelf Sci 30:185-199

Casas B, Varela M, Canle M, González N, Bode A (1997) Seasonal variations of nutrients, seston and phytoplankton, and upwelling intensity off La Coruña (NW Spain). Estuar Coast Shelf Sci 44:767-778

> Delworth TL, Mann ME (2000) Observed and simulated multidecadal variability in the northern hemisphere. Clim Dyn 16:661-676

Fernández E, Bode A (1991) Seasonal patterns of primary production in the Central Cantabrian Sea (Bay of Biscay). Sci Mar 55:629-636

Folland CK, Knight J, Linderholm H, Fereday D, Ineson S, Hurrell JW (2009) The summer North Atlantic oscillation: past, present and future. J Climatol 22:1082-1103

> Fréon P, Barange M, Aristegui J (2009) Eastern boundary upwelling ecosystems: integrative and comparative approaches. Prog Oceanogr 83:1-14

Garcia-Soto C, Pingree RD, Valdés L (2002) Navidad development in the southern Bay of Biscay: climate change and swoddy structure from remote sensing and in situ measurements. J Geophys Res Oceans 107:3118 doi:10.1029/ 2001JC001012

González-Pola C, Lavín A, Vargas Yañez M (2005) Intense 
warming and salinity modification of intermediate water masses in the southeastern corner of the Bay of Biscay for the period 1992-2003. J Geophys Res Oceans 110: C05020 doi:10.1029/2004JC002367

Gregg WW, Casey NW, McClain CR (2005) Recent trends in global ocean chlorophyll. Geophys Res Lett 32:L03606 doi: 10.1029/2004GL021808

Huete-Ortega M, Marañón E, Varela M, Bode A (2010) General patterns in the size scaling of phytoplankton abundance in coastal waters during a 10-year time series. J Plankton Res 32:1-14

IPCC (Intergovernmental Panel on Climate Change) (2007) Climate change 2007. The physical science basis. Contribution of Working Group I to the Fourth Assessment Report of the Intergovernmental Panel on Climate Change. Cambridge University Press, Cambridge

Lavin A, Díaz del Río G, Casas G, Cabanas JM (2000) Afloramiento en el Noroeste de la Península Ibérica. Índices de afloramiento para el punto $43^{\circ} \mathrm{N}, 11^{\circ} \mathrm{O}$ periodo 1990 1999. Datos Resúm Inst Esp Oceanogr 15:1-25

Lemos RT, Sansó B (2006) Spatio-temporal variability of ocean temperature in the Portugal Current System. J Geophys Res Oceans 111:C04010 doi:10.1029/2005JC003051

Leterme SC, Edwards M, Seuront L, Attrill MJ, Reid PC, John AWG (2005) Decadal basin-scale changes in diatoms, dinoflagellates, and phytoplankton color across the North Atlantic. Limnol Oceanogr 50:1244-1253

Llope M, Anadón R, Sostres JA, Viesca L (2007) Nutrients dynamics in the southern Bay of Biscay (1993-2003): winter supply, stoichiometry, long-term trends, and their effects on the phytoplankton community. J Geophys Res Oceans 112:C07029 doi:10.1029/2006JC003573

Longhurst AR (2007) Ecological geography of the sea. Elsevier, Amsterdam

McClain CR, Signorini SR, Christian JR (2004) Subtropical gyre variability observed by ocean-color satellites. Deep Sea Res II 51:281-301

McGregor HV, Dima M, Fischer HW, Mulitza S (2007) Rapid 20th-century increase in coastal upwelling off Northwest Africa. Science 315:637-639

Mendelssohn R, Schwing FB (2002) Common and uncommon trends in SST and wind stress in the California and PeruChile current systems. Prog Oceanogr 53:141-162

Mercado JM, Cortés D, García A, Ramírez T (2007) Seasonal and inter-annual changes in the planktonic communities of the northwest Alboran Sea (Mediterranean Sea). Prog Oceanogr 74:273-293

Submitted: March 26, 2010; Accepted: September 8, 2010
Neveux J, Panouse M (1987) Spectrofluorometric determination of chlorophylls and pheophytins. Arch Hydrobiol 109: 567-581

> Nogueira E, Perez FF, Rios AF (1998) Modelling nutrients and chlorophyll a time series in an estuarine upwelling ecosystem (Ria de Vigo: NW Spain) using the Box-Jenkins approach. Estuar Coast Shelf Sci 46:267-286

Parsons TR, Maita Y, Lalli CM (1984) A manual of chemical and biological methods for seawater analysis. Pergamon Press, Oxford

> Pérez FF, Padin XA, Pazos Y, Gilcoto M and others (2010) Plankton response to weakening of the Iberian coastal upwelling. Glob Change Biol 16:1258-1267

Planque B, Beillois P, Jégou AM, Lazure P, Petitgas P, Puillat I (2003) Large-scale hydroclimatic variability in the Bay of Biscay: the 1990s in the context of interdecadal changes. ICES J Mar Sci 219:61-70

Poularikas AD, Seely S (1991) Signals and systems. PWSKENT, Boston, MA

> Rau GH, Ohman MD, Pierrot-Bults A (2003) Linking nitrogen dynamics to climate variability off central California: a 51 year record based on ${ }^{15} \mathrm{~N} /{ }^{14} \mathrm{~N}$ in CalCOFI zooplankton. Deep-Sea Res II 50:2431-2447

Sherman K, Hempel G (2009) The UNEP large marine ecosystem report: a perspective on changing conditions in LMEs of the world's regional seas. UNEP Regional Seas Reports and Studies, Vol 182. United Nations Environment Programme, Nairobi

Somavilla R, González-Pola C, Rodriguez C, Josey SA, Sánchez RF, Lavín A (2009) Large changes in the hydrographic structure of the Bay of Biscay after the extreme mixing of winter 2005. J Geophys Res Oceans 114:C01001 doi:10.1029/2008JC004974

Swan ARH, Sandilands M (1995) Introduction to geological data analysis. Blackwell Science, London

Valdés L, López-Urrutia A, Cabal J, Alvarez-Ossorio M and others (2007) A decade of sampling in the Bay of Biscay: What are the zooplankton time series telling us? Prog Oceanogr 74:98-114

> van Aken HM (2001) The hydrography of the mid-latitude Northeast Atlantic Ocean. III. the subducted thermocline water mass. Deep-Sea Res I 48:237-267

> Vantrepotte V, Mélin F (2009) Temporal variability of 10-year global SeaWiFS time-series of phytoplankton chlorophyll a concentration. ICES J Mar Sci 66:1547-1556

Wei WWS (1989) Time series analysis: univariate and multivariate methods. Addison Wesley, Boston, MA

Proofs received from author(s): June 23, 2011 